Ludewig, R. \& Lallave, J. (2013), Professional Stress, Discrimination and Coping Strategies: Similarities and Differences between Female and Male Judges in Switzerland. Schultz, U., Shaw, G. (Ed.): Gender and Judging. Oxford: Hart Publishing, 2013, 233-252.

\title{
2.6
}

\section{Professional Stress, Discrimination and Coping Strategies: Similarities and Differences between Female and Male Judges in Switzerland}

REVITAL LUDEWIG AND JUAN LALLAVE

\begin{abstract}
This chapter contributes towards understanding the effect of gender on judging. It examines whether the experiences of women and men judges with their profession support a gender differences or a gender similarities hypothesis. Women and men judges in Switzerland $(N=243)$ were asked to rank their experiences with professional difficulties, coping strategies, work-life balance, satisfaction and discrimination to determine whether there were differences or similarities due to gender. Significant differences between women and men judges' mean rankings support a gender differences hypothesis, while differences not significant support a gender similarities hypothesis. Findings upheld gender similarities for experiences with professional difficulties, the use of most of the coping strategies, most experiences with work-life balance and satisfaction. Findings upheld gender differences for some coping strategies and experiences of discrimination. Women judges reported using mediation and social support as coping strategies and experienced gender discrimination significantly more than men did. Overall, 27 per cent of findings support a gender differences hypothesis, while 73 per cent support a gender similarities hypothesis.
\end{abstract}

\section{INTRODUCTION}

$\neg$ HIS CHAPTER REPORTS on the relative psychological experiences of men and women judges with their profession in Switzerland. It involves rethinking the tension between gender differences and gender similarities. Kimball (1994) stresses the importance of both perspectives 
and the tension between them. Early last century when women were outsiders in most professions, Hollingworth (1918) argued for similarities and against gender differences to encourage the inclusion of women. Today, we maintain that it is reasonably clear that women and men are equally qualified to judge. Hyde (2005: 590) confronts an, 'overinflated gender differences model popular in advertising', which is saturated in public opinion, the media and many academic papers. The gender differences hypothesis holds that men and women are vastly or primarily psychologically different. Hyde finds support for a gender similarities hypothesis, which holds that while men and women may differ in some psychological variables, they are similar in most. The similarities hypothesis has not been specifically discussed in understanding judges' professional experiences.

Zuriff (2006: 641) reminds us that, 'judgments of similarity and difference are psychological, not scientific'. He stresses that one must 'determine the psychological importance of each dimension in human judgments of similarity and difference' and urges that we not dismiss 'gender differences dependent on context' and, 'consistent with social-role theory'. Davies and Shackelford (2006: 641) 'generally agree with the gender similarities hypothesis' but argue that 'gender differences may be more profound and have greater societal costs than Hyde suggested'. They recommend 'an evolutionary psychological perspective' to investigate gender differences and limit 'their associated costs'.

As clinical and forensic psychologists, we examine this controversy of general gender differences and similarities as a factor among judges' experiences. Differences in life experiences seem to support claims that women might be psychologically different from men. This may contribute to differences in their experiences of judging. In psychology, differences may lead to distancing, while similarities contribute to empathy and identification. Both of which can lead to bias as Gutheil and Datillio (2007: 34) observe 'The largest barrier to acceptance of human diversity is the deep-seated, prejudice-laden worldview of our own Ids'.

Women judges may encounter similar difficulties in their work as men judges, provided they confront similar caseloads. They both may learn and use the same coping strategies. However, as psychologists we expect that judges' psychological experiences should reflect gender differences. Women may continue to experience discrimination more often than men may observe within the profession, while increasing numbers of women judges and the profession's stance on gender neutrality may mask or silence these differences.

Women's democratic right to participate in public decision-making supports the need to increase their numbers on the bench. The presence of women judges in Switzerland is a recent development, since judges in Switzerland are politically elected and women only acquired a voice and voting rights at the federal level in 1971 . While women did not have voting 
rights, they could not run for election as judges. However, in a short span of 39 years we note a rapid improvement.

Today, the value of gender equity is an unqualified good. In a federal census in Switzerland in 2000, women represented 30.8 per cent among judges and state attorneys, 23.2 per cent among top-level judges, 23 per cent among second and third level judges and 28 per cent among first level judges (Niquille, 2007). Most cantons began to include women as judges in 1971 and 1972 when they got voting rights at federal level-with some exceptions. In Basel, women were admitted as early as 1967 and in Appenzell as late as 1990. In 1974, Margrith Bigler-Eggenberger became the first regular federal judge (Ludewig, Weislehner and Angehrn, 2007). However while women make up over 50 per cent of all law students, they fall 20 per cent short of the 50 per cent balance for equal representation within the profession. To achieve this ideal representation of gender balance, women must want to be judges. It is therefore important to understand women's experiences as judges (Malleson, 2003).

The recent history of women's participation as judges in Switzerland may explain why there are very few studies. In this study we were interested in understanding women's psychological experiences as judges relative to that of men. Considering the recent inclusion of women, we sought information on their integration in the profession. We expected that women and men would report evidence to support a gender differences hypothesis in their psychological experiences within their role as judges. This would be an alternative to a Nil hypothesis consistent with Hyde's notion of gender similarities, consistent with Tversky (1977: 340) who observes that 'common features are weighed more heavily in judging similarities' whereas distinctive features are weighted more heavily in judging dissimilarity.

\subsection{Perceptions of Emotional Experiences in Judging}

This chapter focuses on women and men judges' experience with professional stress, coping strategies, work-life balance, satisfaction and discrimination, beyond the question of differences in decision-making. Judges' work is stressful. Their daily concerns involve 'workloads, sentencing, incompetent attorneys, finances and family life' (Menninger, quoted in Middleton, 1981: 1101). They confront 'cases requiring active judicial management' with 'inadequate or abusive representation' and 'vulnerable clients' (Portnoy, 2004: 131-32). Judges also worry about the consequences of their decisions, and their effective use of skills (ibid).

Although judging involves a full range of emotions, the emotions evoked by criminal and civil procedures are often negative. In criminal cases, defendants 'may be fearful or hostile, while victims are distressed or angry'. In civil cases, parties 'may feel frustrated and annoyed at having to go to court' 
(Anleu and Mack, 2005: 591). Disclosures of poor financial management may prove embarrassing in cases involving debts. In domestic violence, parties may be either frightened, or openly hostile. Thus, court users experience anger, fear, uncertainty and intimidation and their emotional displays can cause judges themselves to experience-and sometimes express-strong emotions. 'Magistrates must often regulate their own emotions and those of some court users' (ibid: 590). Discerning how deeply judges experience their work is not a simple task and beyond the scope of this chapter.

'Order and decorum' require that judges keep a lid on feelings and 'remain objective, dispassionate, above the fray'. This adds to their burden. In response to stress, judges must 'unobtrusively and acceptably' control 'the urge to scream' (Menninger, quoted in Middleton, 1981: 1100). Judges' responsibilities make their stress worse than they might in other professions. In a study by Menninger, 50 per cent of 254 judges 'felt comfortable with how they handled stress in their lives and 11 per cent did not know how to handle that stress' (ibid). 'Judges are subject to a wide range of physical and emotional problems and stressors, but often don't get the help they need' (Zimmerman, 2006: 10). Portnoy (2004: 132) found positive correlations between internal states associated with stress and 'feelings of tension, feeling disliked by others, feeling irritable with others, not feeling appreciated, negative feelings about professional role, and difficulty in making decisions'. Menninger found 'references to internal pressures': living up to expectations, struggle for 'quality and thoroughness' and concern over the best decision. These pressures challenge judges' ability to maintain emotional balance and equilibrium because they 'can't always please everyone' but 'must also penalise or punish' (Menninger, quoted in Middleton, 1981: 1101). Negative emotions remain a source of judges' stress. Distancing and depersonalisation are often ineffective coping strategies. They can lower judges' job satisfaction and disrupt their work and family life balance. Imbalances between work and family life may cause women more stress because they experience greater responsibility for family life (Schultz and Shaw, 2008: 1; Sander and Hartmann, 2009). Most judges report that they lead happy personal lives and their most pressing task is 'to keep from being overwhelmed' in stressful circumstances.

\subsection{Discrimination}

Gender differences can be used to discriminate against women or to focus on 'positive human characteristics undervalued because they are symbolically associated with women' (Kimball, 1994: 389). Gender similarities can also be used to support the status quo or to 'support political and social equality for women' (ibid). Hollingworth (1918) stressed similarities' arguments towards the 'integration of women' into 'the existing social and economic 
system'. Kimball (1994: 388) argues that differences were 'viewed as dangerous' because in 'our hierarchical world' they were 'used to exclude women, to reinforce oppression, and to minimise the role of coercion in the subordination of women'. Differences tend to reduce 'real women and men to stereotypes'. To 'counter the preponderance of men in positions of power and prestige' similarities focus on 'intellectual skills and social competencies'. Scientific justification for political equality aims to show that gender differences do not exist or are 'too small to explain gender differences in the labour force' (ibid).

A 'sense of connectedness, concern with human relationships, and caregiving' are 'characteristics that women bring to human culture more than men' do. The political goal of differences 'is not equality, but rather a more humane world that incorporates traditional feminine values as a central human focus' (ibid: 389).

Discrimination of women in Switzerland changed with their right to vote in political elections in $1971^{1}$ as described above. The growing presence of women judges does not automatically undo discrimination and some of the anchors persist (Ludewig and Weislehner, 2007: 69). While, 'women's presence serves as a necessary base line, some believe that the legal profession remains inhospitable to incorporating women' (Kohen, 2008: 113; see also Schultz and Shaw, 2003).

\section{QUESTIONS AND METHODS}

This research, conducted at the University in St Gallen, Switzerland, enquired into five factors:

1. Professional difficulties weighing heavily on judges, such as time pressure, problems with colleagues, decision-making and professional stress. ${ }^{2}$

2. Cognitive and behavioural coping strategies.

3. Work-life balance.

4. Pleasant experiences of satisfaction.

5. Unpleasant experiences of discrimination and perceptions of professional problems at the meta-level.

A qualitative-phase involved 31 Swiss women and men judges and 80 other members of the legal profession. A quantitative-phase employed a written questionnaire designed on the basis of an analysis of initial interviews.

\footnotetext{
1 Of 38 Supreme Court Justices in Switzerland, 11 are women.

2 While we briefly mentioned decision-making, it is not the primary focus of this chapter. A paper on this subject is in progress.
} 
We enquired into gender differences and gender similarities by asking women and men judges to rank their own experiences with these factors. ${ }^{3}$

We tested the 'Nil hypothesis' that differences were not significant and pursued a gender differences hypothesis consistent with the common notion that women and men differ in their decisions. The sample for this questionnaire consisted of 247 professionally trained women and men from 50 Courts in German-speaking Switzerland. The analysis included 243 questionnaires because four respondents did not indicate gender. Of the replies, 28 per cent of them were from women; this percentage is well in line with the overall percentage of women judges. ${ }^{4}$

Using respondents' ranks, we computed the mean for each gender. Then we compared the means for women with the means for men. If we found that the means were not significantly different, we accepted the Nil in support for the gender similarities hypothesis. If we found that the means were significantly different, we rejected the Nil in support for the alternative gender differences hypothesis.

\section{RESULTS}

\subsection{Professional Difficulties}

All professions have their own particular burdens. Medical doctors feel stress dealing with death (Hohner, Grote, Hoff and Dettmer, 2003); teachers with students (Wagner, Christ and Van Dick, 2003); and judges with difficulties in legal decision-making and pressures from litigant parties. Other general stressors common to all professions include time pressures and problems with colleagues.

\subsubsection{Time Pressure}

Time pressure was the most frequently reported difficulty by 98.6 per cent of judges. Litigant-parties' pressure for a swift ruling, but also diligent and good judicial work takes time. Thus, judges experience conflict between quality and quantity. Working on less complicated cases may postpone work on ones that are more complex. Women and men judges ranked their experience with time pressure similarly. The mean rank for women was 3.53 and 3.6 for men. Only 1.4 per cent of all judges denied the experience of time pressure as a professional difficulty.

${ }^{3}$ Rankings based in a 5 point Likert scale (from 1 to 5 ) for most factors except 'satisfaction', based on a 10 point scale (from 1 to 10 ).

${ }^{4}$ See above p 231. 


\subsubsection{Problems with Colleagues}

While 71 per cent of judges reported difficulties with colleagues, there were no significant gender differences among judges' rankings. The mean for women was 2.03 and 1.97 for men.

\subsubsection{Decision-making}

Judges engage daily in decision-making under potentially stressful conditions. In civil law, conflicts between litigant parties involve irreconcilable differences, for example, which parent receives custody of the child after a divorce. In criminal law, judges must decide between guilt and innocence. Although 98.4 per cent of judges reported difficulties in decision-making, there were no significant differences in ranking by gender. The mean for women was 2.54 and 2.56 for men. Stress from problems between litigant parties was reported by 85.7 per cent of judges; 14.3 per cent denied stress. There were no significant differences in ranking by gender; the mean for women was 2.08 and 2.05 for men.

\subsubsection{Professional Stress}

On leaving the office, judges do not separate easily from emotions and difficult cases and 90 per cent reported difficulties affecting their private life. They think about escalated situations, conflicting parties and legal decision-making in their free time. The mean rank for women was 2.62 and 2.47 for men. Only 10 per cent of judges denied such difficulties. Encounters with stress can lead to health impairments. While they do not occur daily, 57 per cent of women judges and 62 per cent of men judges reported difficulties sleeping due to unusual work stress such as, when dealing with custody cases involving kidnapping, highly publicised cases or strong disagreements within a five-judge panel. The mean rank for women concerning sleep disorders was 1.82 and 1.85 for men. We found no significant difference in sleep disorders due to gender independent of age.

\subsubsection{Subjective Perception of Professional Problems}

Judges differ in their perception that women have more difficulties in their judging role than men do. Women judges perceive they sometimes face greater difficulties than men. Men judges perceive that women seldom have greater problems than men. The mean rank for women was 2.74 and significantly higher than 2.04 for men. ${ }^{5}$

\footnotetext{
5 T-Test for women having it more difficult than men: $\mathrm{t}=4.616, \mathrm{df}=199, \mathrm{p}<.000$.
} 
Table 1: Professional difficulties

\begin{tabular}{llc}
\hline $\begin{array}{l}\text { Professional difficulties supporting a gender differences } \\
\text { hypothesis }\end{array}$ & \multicolumn{2}{c}{ Mean } \\
\cline { 2 - 3 } & Women & Men \\
\hline $\begin{array}{l}\text { Do women judges generally have it more difficult than men } \\
\text { judges do? }\end{array}$ & $2.74^{*}$ & $2.04^{*}$ \\
\hline $\begin{array}{l}\text { Professional difficulties supporting a gender similarities } \\
\text { hypothesis }\end{array}$ & \multicolumn{2}{c}{ Mean } \\
\cline { 2 - 3 } (These differences in means are statistically not significant) & Women & Men \\
\hline Time pressure & 3.53 & 3.68 \\
Difficulties with work colleagues & 2.03 & 1.97 \\
Difficulties with decision-making & 2.54 & 2.56 \\
Difficulties with litigant parties & 2.08 & 2.05 \\
Professional work stress and emotions interfere with & & \\
personal life and free time & 2.62 & 2.47 \\
Difficulties sleeping & 1.82 & 1.85 \\
\hline
\end{tabular}

"Statistically significant difference $\mathrm{p}<.000$ (Likert scale from: not at all $=1$ to $5=$ very much, $0=$ do not know)

From seven items on professional difficulties, six items or 85 per cent conformed to the criteria for similarities and only one item, or 14 per cent, conformed to the criteria for differences. The importance of this single difference is that it represents women's self-perception and men's perception of women.

\subsection{Coping Strategies}

Coping strategies may facilitate reasoning, change attitudes, lower the impact of emotions and modify the influence of perceptions of stressors. These include cognitive, emotional, behavioural and tactical attempts to minimise a conflict and to reduce stress. Women and men judges, consciously or unconsciously, employ similar strategies to reduce psychological stress temporarily or permanently. We looked at four types of coping strategies (Felsten, 1998):

1. Cognitive-emotional coping strategies.

2. Emotional-avoidance coping strategies.

3. Tactical coping strategies.

4. Social support coping strategies. 


\subsubsection{Cognitive-emotional Coping Strategies}

Cognitive-emotional coping strategies help reduce stress by restructuring the problem or by controlling emotional responses to the problem. The first facilitates reasoning by organising values in a hierarchy. The second facilitates objective detachment by distancing oneself from difficult emotions. For example, in a quarrel with a friend, one can decide that it was a small quarrel considering the value of the friendship, or that such a friendship is not important enough to ignore a principle. We expected but found no significant gender differences. Women and men use the same cognitive-emotional coping strategies to the same extent (Folkman and Lazarus, 1980).

Value-hierarchy: Constructing a value hierarchy is a cognitive strategy to cope with difficulties in decision-making by organising a set of values. For example, if a single mother with a two-year-old daughter is found guilty of a crime, in sentencing, judges must balance two values: adhering to legal penalties associated with the verdict and protecting the child's need for mother, care and education. A value-hierarchy helps determine an appropriate sentence and resolve judges' stress. In their use of a valuehierarchy, the mean for women's rank was 3.09 almost identical with 2.99 for men.

Objective distancing: This is a detachment strategy to cope with a difficult case. It facilitates concentrating on the legal criteria and goal by distancing oneself from the fate of the parties. It may simplify decisionmaking, but can lower justice quality by discounting emotional and perhaps more humane considerations. Women ranked using objective distancing as frequently as men did. The mean for women was 3.34 and 3.26 for men.

\subsubsection{Emotional-avoidance Coping Strategies}

Emotional-avoidance prevents professionally difficult and stressful situations from overwhelming judges emotionally in their personal lives. It enables disengaging from particular stressors that may persist after leaving the office. Women and men use emotional-avoidance similarly (Felsten, 1998).

Suppression: This is a cognitive strategy to dismiss thoughts associated with a negative stressor from particularly difficult cases. Men judges ranked their use of suppression slightly higher than women judges did. The mean was 2:36 for men and 2.20 for women.

Distraction: This is an action strategy, whereby persons engage in other activities in order to temporarily reduce stress. Women judges ranked their use of distraction slightly higher than men judges did. The mean was 2.83 for women and 2.70 for men. However, these differences are not statistically significant. 


\subsubsection{Tactical Coping Strategies}

Tactical strategies focus on actions to facilitate resolving cases and reduce stress. In a dispute with a friend one could apologise, send flowers or talk directly to defuse the conflict. What action-strategies are available to judges in stressful situations? In a civil case, a sentence favouring either party will be stressful, if parties seem equally right. To satisfy both parties, this dilemma is better resolved by the use of court settlement (Vergleich) or external mediation.

Court settlement (Vergleich): Judges can aid parties to reach an agreement without pronouncing judgment by court settlement. Women and men judges ranked their use of court settlement similarly, consistent with a role constraint hypothesis. The mean rank for women was 3.71 and 3.75 for men. ${ }^{6}$

External mediation: External mediators can help resolve conflicts outside court. Using non-partisan mediators, judges can avoid the stress in sentencing, except when mediation is not successful. Use of external mediation supports a socialisation hypothesis (Ptacek, Smith and Zanas, 1992) because women and men are socialised differently, despite their similar training. Women ranked their use of this action strategy significantly higher than men judges did. The mean for women was 2.52 , but only 1.88 for men. ${ }^{7}$ This difference is statistically significant.

\subsubsection{Social Support Coping Strategies}

Social support like talking over problems with others can reduce internal stress. Research reflects gender differences in the use of social support (ibid). Therefore, we expected women to use social support more frequently than men do. We asked judges whether they used discussions of cases and/ or conversations with family and friends as a means of coping with stress.

Discussions on cases: Women judges sought social support by direct discussions of cases more than men did. The mean for women was 3.94 and 3.42 for men. ${ }^{8}$

Conversations with family and friends: Women judges sought social support through conversations with family and friends more than men did. The mean for women was 3.54 and 2.94 for men judges. ${ }^{9}$ These differences are statistically significant.

\footnotetext{
${ }^{6}$ T-Test for court settlement: $\mathrm{t}=2.589, \mathrm{df}=95, \mathrm{p}<.003$.

7 T-Test for external mediation: $\mathrm{t}=3.467, \mathrm{df}=202, \mathrm{p}<.002$.

8 T-Test for direct discussions: $\mathrm{t}=3.578, \mathrm{df}=203, \mathrm{p}<.000$.

9 T-Test for conversations with family and friends: $\mathrm{t}=3.901, \mathrm{df}=229, \mathrm{p}<.000$.
} 
Table 2: Coping strategies

\begin{tabular}{llc}
\hline Coping strategies supporting a gender differences hypothesis & \multicolumn{2}{c}{ Mean } \\
\cline { 2 - 3 } (These differences in means are statistically significant) & Women & Men \\
\hline $\begin{array}{l}\text { Women use mediation slightly more often than men do } \\
\text { (referrals outside court) }\end{array}$ & $2.52^{*}$ & $1.88^{*}$ \\
$\begin{array}{l}\text { Women use direct discussions for social support more than } \\
\text { men do }\end{array}$ & $3.94^{*}$ & $3.42^{*}$ \\
$\begin{array}{l}\text { Women use conversations with family and friends for } \\
\text { social support more than men do }\end{array}$ & $3.54^{*}$ & $2.94^{*}$ \\
\hline Coping strategies supporting a gender similarities hypothesis & \multicolumn{2}{c}{ Mean } \\
\cline { 2 - 3 } (These differences in means are statistically not significant) & Women & Men \\
\hline Hierarchical values & 3.09 & 2.99 \\
Objective distancing & 3.34 & 3.26 \\
Men use avoidance slightly more than women do & 2.20 & 2.36 \\
Court settlement (Vergleich) ie, judge assisted agreement & 3.71 & 3.75 \\
Women shift to other activities slightly more than men do & 2.83 & 2.70 \\
\hline
\end{tabular}

"Statistically significant difference $\mathrm{p}<.003$-(Likert scale from: not at all $=1$ to 5 = very much, $0=$ do not know)

Women and men judges' use of cognitive-emotional and avoidance coping strategies conforms to the criteria for a gender similarities hypothesis, while the use of tactical and social support strategies conforms to the criteria for a gender differences hypothesis. Women judges ranked their use of nonpartisan mediation as social support at the action level as well as discussions on cases and conversations with family and friends higher than men did. Overall, we observed more gender similarities than differences. From eight items on coping strategies, five items or 62.5 per cent conformed to the criteria for similarities, and three items or 37.5 per cent conformed to the criteria for differences.

\subsection{Work-life Balance}

This study found employment rate imbalances among judges: 72 per cent of men occupied 79.3 per cent of full-time posts compared with 20.7 per cent of posts occupied by women, while 63.5 per cent of women work part-time compared with 24.3 per cent of men.

Both women and men judges struggle to maintain work-life balance. Stressful imbalances occur when professional life affects private life or private life hinders professional goals. 


\subsubsection{Impact of Profession on Personal Life}

Women and men judges equally feel that their professional life affects their private life. The mean for women was 2.46 and 2.56 for men. This slight difference is statistically not significant.

\subsubsection{Impact of Personal Life on Professional Goals}

Women ranked feeling that their private life hinders their professional goals significantly higher than men did. The mean for women was 2.52 and 1.87 for men. ${ }^{10}$

Table 3: Work-life balance

\begin{tabular}{llc}
\hline Work-life balance & \multicolumn{2}{c}{ Mean } \\
\cline { 2 - 3 } & Women & Men \\
\hline $\begin{array}{l}\text { Women are more likely to feel their private lives hinder their } \\
\text { professional goals }\end{array}$ & $2.52^{*}$ & $1.87^{*}$ \\
$\begin{array}{l}\text { Women and men feel that their profession is at the expense } \\
\text { of their private life }\end{array}$ & 2.46 & 2.56 \\
\hline
\end{tabular}

"Statistically significant difference $\mathrm{p}<.000-$ (Likert scale from: not at all $=1$ to $5=$ very much, $0=$ do not know)

From two items on work-life balance, one item conformed to the criteria for similarities and one item to the criteria for differences. In contrast with men, women judges feel that their private life hinders their professional goals whether they have children or not and independent of the number of children.

Men judges move along career steps, while women judges progress less smoothly for the sake of their family. While both must coordinate various objectives in their lives, women may value goals in partnership, family and children more than men do. Women's conscience may limit their opportunities, when promotions conflict with their performance as good mothers:

Women want to be perfect mothers, partners and judges. They feel more responsible in their family role to housework and private life. Their diverse goals may cause them more stress. Younger judges, regardless of gender, are more likely to feel that their private life affects their professional goals. This represents a fundamental conflict for younger women judges with smaller children who require more time and attention. ${ }^{11}$

10 T-Test for effect of personal life on professional career goals: $\mathrm{t}=4.512, \mathrm{df}=240, \mathrm{p}<.000$.

11 ANOVA Analysis of variance for age of women and men judges: $\mathrm{F}=2.840, \mathrm{df}=240$, $\mathrm{p}<.025$. 


\subsection{Satisfaction}

Satisfaction involves conscious and unconscious expectations and actual conditions. We examined experience of satisfaction in job, family life and standard of living.

\subsubsection{Job Satisfaction}

Judging is highly valued. It combines public reputation, prestige and respect. These positive factors are available to both women and men judges. Judges enjoy greater autonomy, greater possibility for part-time work and more compatibility with family life compared with attorneys and doctors. Women and men judges ranked their satisfaction with work very high. The mean for women was 8.22 and 8.37 for men.

\subsubsection{Family Life Satisfaction}

Women and men ranked satisfaction with their family life very high. The mean for women judges was 8.39 and the mean for men was 8.32 .

\subsubsection{Standard of Living}

Women and men judges are content with their standard of living. Women's mean of 8.85 is not statistically significantly different from men's mean of $8.49 .{ }^{12}$

While their wage scales are identical, women judges may be more satisfied with their standard of living. They have different expectations and must be more adaptable than men. Women's earnings in the judiciary are much higher than they would be in other professions. Men are accustomed to higher wages in other professions. Thus, while equally content with their standard of living, men seem less content with their incomes.

\section{Table 4: Job satisfaction}

\begin{tabular}{lcc}
\hline Job satisfaction supports a gender similarities hypothesis & \multicolumn{2}{c}{ Mean } \\
\cline { 2 - 3 } (These differences in means are statistically not significant) & Women & Men \\
\hline Very high levels of job satisfaction & 8.22 & 8.37 \\
Women are slightly more satisfied with their family than men & 8.39 & 8.32 \\
Women are slightly more satisfied with their incomes than men & 8.85 & 8.49 \\
\hline
\end{tabular}

(Likert scale from: not at all satisfied $=1$ to $10=$ very satisfied)

$12 \mathrm{P}$-value for differences in men and women's content with their standard of living: $\mathrm{P}<.067$. 
All three items on job satisfaction or 100 per cent conformed to the criteria for similarities.

\subsection{Discrimination}

Do women and men judges experience disadvantages within the profession due to gender discrimination or canton affiliation?

\subsubsection{Canton Affiliation}

There are 26 cantons in Switzerland. A small percentage of women and men judges, 7.5 per cent and six per cent respectively, reported feeling discriminated because they did not live and work in the same canton by colleagues, for example other judges, lawyers or by parties.

\subsubsection{Gender}

Women and men judges differ in their experiences of gender discrimination at work. Statistically significant, 52 per cent of women judges and five per cent of men judges reported experiences of gender discrimination (see figure 1 below). ${ }^{13}$

Table 5: Experiences of discrimination

\begin{tabular}{lcc}
\hline Experiences of discrimination & \multicolumn{2}{c}{$\%$} \\
\cline { 2 - 3 } & Women & Men \\
\hline $\begin{array}{l}\text { Women and men experience similar discrimination due to } \\
\text { canton affiliation. }\end{array}$ & 7.5 & 6.0 \\
$\begin{array}{l}\text { Women experience more professional disadvantages due } \\
\text { to gender discrimination than men do. (This difference in } \\
\text { means is statistically significant) }\end{array}$ & $52.0^{*}$ & $5.0^{*}$ \\
\hline
\end{tabular}

"Statistically significant difference $\mathrm{p}<.000$

From two items on discrimination, one conformed to the criteria for similarities due to canton affiliation, and one conformed to the criteria for differences due to gender discrimination.

13 Mann-Whitney U-Test for differences in experiences of gender discrimination: Asymp. Sig. (2-tailed) p > .000. 


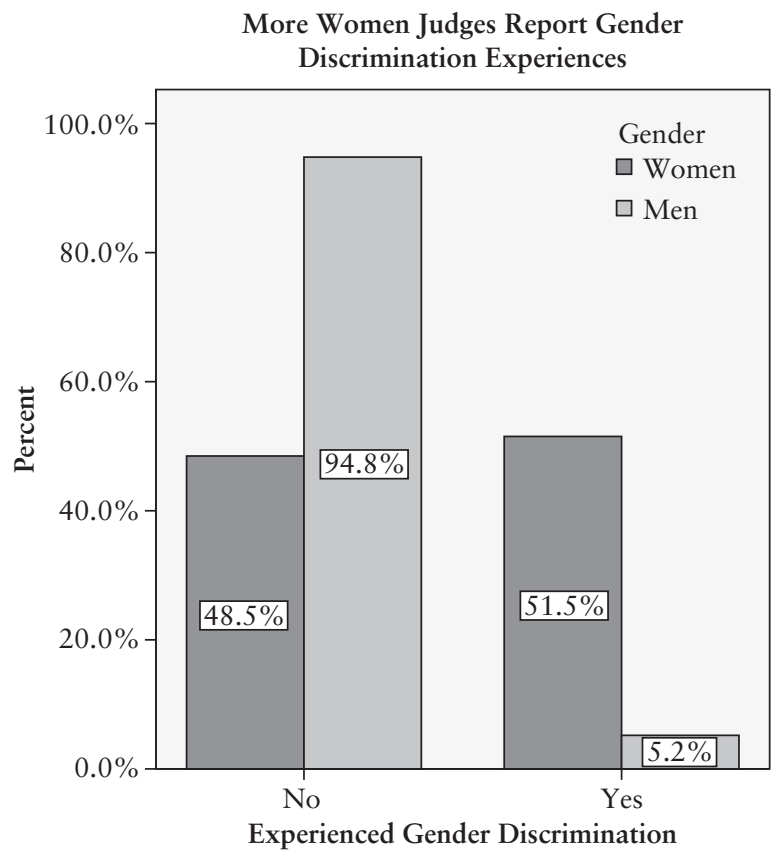

Figure 1: Experienced Gender Discrimination

Women with more than nine years of work experience reported more gender related discrimination than did women with fewer than nine years' experience. Perhaps the system has improved. Women working over 15 years were the first women judges in Switzerland and had more boundaries to overcome. They may have been exposed to discrimination more than younger women judges, who today encounter better conditions. Perhaps younger women judges may not have had time to experience discrimination and their experiences may increase in time.

However, women judges report only isolated incidents and do not want to criticise the judicial system as such. For example, one woman judge described how an expatriate male ignored her question during the court proceedings or rather only answered the male judge although she was the top judge in the case. Another woman judge reported that an older attorney did not take her seriously at the beginning, but this changed in the course of time. Women judges reported eighteen incidents of discrimination from court litigant parties, eleven incidents from attorneys, eight incidents from judges and six incidents from political parties. 


\section{DISCUSSION: GENDER SIMILARITIES AND DIFFERENCES HYPOTHESIS}

At one end of the spectrum of views on gender differences in judging is the view that women and men judges' professional experiences are different; at the other, is the view that there are considerable similarities. Comparing the means of rankings by women and men judges in Switzerland, we examined whether their experiences support a gender similarities or gender differences hypothesis. We found more evidence to support a gender similarities hypothesis in the experiences of judges in Switzerland. From a total number of 22 items, 16 items or 73 per cent conformed to the criteria for similarities and six items or 27 per cent conformed to the criteria for differences.

Women and men judges reported more similarities than differences in their experiences of professional difficulties. Women and men judges also use many similar coping strategies. They employ value hierarchies, objective distancing, court settlements, mediation, social support and avoidance, suppression and distraction. They reported similar sleeping difficulties and professional stress due to hindrances from an inability to separate their work from their personal lives. Both experienced similar psychological and physical complications. Women and men judges were equally content with many aspects of their lives, with similarities in job satisfaction, family life satisfaction and standard of living.

Yet, we found some significant gender differences. Women judges used external mediation and social support, ie, direct discussions on cases and conversations with family and friends as coping strategies significantly more than men judges. Women judges also feel that their judging role is more difficult for them than for men. They feel that they have a harder task than men, that their personal lives interfere with their professional goals and that they experience more gender discrimination. Although these differences do not appear sufficient to support a gender differences hypothesis, they are important in an assessment of the subjective perceptions of women and men judges.

The following four considerations may help to explain why there are more gender similarities than gender differences.

First, similar professional difficulties support a role constraint hypothesis. Women and men judges have similar roles. They undergo the same legal studies and share the same socialisation. This influences their awareness, their thinking, their behaviour and their experience of stressors.

Secondly, gender does not automatically enhance a person's ability to cope with difficulties. Women appear to use some coping strategies more than men, which may be consistent with common gender differences. Social support and mediation involve seeking help to achieve greater social competence, rather than relying solely on self-confidence. Thereby they lower their own experiences of stress. This is a positive difference, which can 
lead to greater objectivity. It partly reflects a difference in the socialisation of women and men. Based on this social orientation we expected women would use suppression less than men would. We found this not to be the case. This may be due to the influence of men's examples as precursors on the bench. Suppression is only a short-term strategy that can be very problematic when applied consistently in coping with all circumstances because it avoids dealing with important factors.

Thirdly, work-life balance interacts with job satisfaction. Like women, men who decide to become judges tend to have a high sense of family responsibility. This does not mean that men do as much work in the home or with children as women. Although they may do more than men who choose to become company lawyers, perhaps they feel they should do even more. Thus, men judges like women experience stress when their work interferes with family life. Women, however, also feel that the stress within family life can hinder their professional goals. Thus, unlike men, women experience the challenge of a two directional stress between profession and family. They feel more obliged to cope with multiple tasks and bear the ultimate social responsibility for the family, household and child rearing or education. Therefore, they place higher demands on themselves to live up to the profession's expectation of their role and performance. This leads them to estimate their work as more stressful and more demanding than that of their male colleagues.

Fourthly, judging remains a traditionally male dominated profession. Women continue to experience gender discrimination, but may not want to alienate themselves from their male colleagues by claiming discrimination. Both men and women may tend to normalise the presence of gender discrimination. Despite the increase in numbers on the bench, women may still perceive themselves as surrogates. Men are also conscious of the controversies surrounding gender discrimination and feel that they have to treat women equally. Women may minimise the severity of their experiences and prefer not to talk about them. Men may not express or acknowledge their own feelings or tendency to discriminate and consciously control them. Both may therefore underestimate the psychological differences. Men may not want to represent views that interfere with women's potential contribution, out of collegial respect or political correctness. Women judges do not want to criticise the system and instead tend to reduce their own subjective feelings of disadvantage or discrimination to isolated single events. The younger generation of women judges who may have experienced fewer disadvantages, do not talk about their experiences or are not in touch with them. In either case, they may deny experiences of gender discrimination.

Women often attribute their successes and failures differently from men. Women attribute their success to favourable outer circumstances, to luck or to coincidence and personalise responsibility for failures (Maag, 2007). 
Women may account for difficulties by their gender affiliation. Men portray the opposite pattern: they account for their success internally and attribute their failures externally; they feel they are successful because they mastered special tasks by their own skills and competence and feel that failures are due to unfavourable outer circumstances. Under the positive influence of women, men may become more socially oriented, but attribute it to their own doing. Women may feel self-conscious, underestimate their potential contribution and strongly adhere solely to an objective interpretation and application of the law. Similarities between women and men judges fit the role constraint hypothesis. Women and men judges have the same professional role with similar stressors and deal with difficulties using many of the same coping strategies. This minimises the likelihood of differences between women and men judges as they interact and mutually influence each other in their daily work.

Gender differences and similarities both have their value and the tension between them accentuates the benefits of each of them.

In the early 1900s, women were excluded from the professions because they were different. In the Western world women, as outsiders, began to stress their similarities in order to justify entering the professions. Similarities have been crucial in justifying equality and thereby increasing the number of women in the profession. In a formerly male justice system, the socialisation process of judges and judging was obviously gendered.

Today women judges have integrated well into the system. As insiders now, both genders can emphasise their differences from within the profession in order to improve the quality and values of judging. Gender differences may influence the quality of judging by including the unique contribution of women and men. Both benefit from each other's contribution whether they are different or similar. Their mutual influence in the socialisation process serves to diminish the appearance of differences and to increase the appearance of similarities in the profession. With the increase of gender diversity within the judging profession in Switzerland, we observe many similarities between men's and women's experiences. They are highly satisfied with their work, the prestige and standard of living and value many facets of the profession. Men may appear now more socially and community oriented than before, and women may seem more principled or rule oriented than formerly anticipated (Angehrn and Ludewig, 2007).

Overall, 72 per cent of the considerations in this study conformed to the criteria for similarities and 27 per cent to the criteria for differences between men and women judges' experiences with their work in Switzerland. The differences observed remain relevant and merit further consideration. The tension between similarities and differences can be compared to the tension between experiencing one's own work and perceiving the work experiences of others. 


\section{REFERENCES}

Angehrn, E and Ludewig, R (2007) 'Erleben und verarbeiten Richterinnen Moraldilemmata anders als Richter? Literatur- und Interviewanalyse' in R Ludewig, K Weislehner and E Angehrn (eds), Zwischen Recht und Gerechtigkeit: Richterinnen im Spiegel der Zeit (Bern, Stämpfli).

Davies, APC and Shackelford, TK (2006) 'An Evolutionary Psychological Perspective on Gender Similarities and Differences’ 61(6) American Psychologist 640.

Felsten, G (1998) 'Gender and Coping: Use of Distinct Strategies and Associations with Stress and Depression' 11 Anxiety, Stress and Coping 289.

Folkman, S and Lazarus, RS (1980) 'An Analysis of Coping in a Middle-aged Community Sample' 21 Journal of Health and Social Behavior 219.

Gryski, G, Main, E and Dixon, W (1986) 'Models of State High Court Decision Making in Sex Discrimination Cases' 48 Journal of Politics 143.

Gutheil, TG and Datillio, FM (2007) Practical Approaches to Forensic Mental Health Testimony (Baltimore, Lippincott Williams and Wilkins/Wolters Kluwer).

Hoff, E, Grote, S, Dettmer, S, Hohner, HU and Olos, L (2005) 'Work-Life-Balance: Berufliche und private Lebensgestaltung von Frauen und Männern in hoch qualifizierten Berufen' 49(4) Zeitschrift für Arbeits- und Organisationspsychologie 196.

Hohner, HU, Grote, S, Hoff, EH and Dettmer, S (2003) 'Berufsverläufe, Berufserfolg und Lebensgestaltung von Ärztinnen und Ärzten’ in A Abele, EH Hoff and HU Hohner (eds), Frauen und Männer in akademischen Professionen. Berufsverläufe und Berufserfolg (München, Asanger).

Hollingworth, LS (1918) 'Comparison of the Sexes in Mental Traits' 15 The Psychological Bulletin.

Hyde, JS (2005) 'The Gender Similarities Hypothesis' 60(6) American Psychologist 581.

Kimball, MM (1994) 'The Worlds We Live In: Gender Similarities and Differences' 35(4) Canadian Psychology/Psychologie canadienne 388.

Kohen, B (2008) 'Family Law Judges in the City of Buenos Aires: A View from Within' 15(1-2) International Journal of the Legal Profession 111.

Ludewig, R, Weislehner, K and Angehrn, E (2007) (eds), Zwischen Recht und Gerechtigkeit: Richterinnen im Spiegel der Zeit (Bern, Stämpfli).

Ludewig, R and Weislehner, K (2007) 'Einstieg, Aufstieg, Entfaltung: Drei Generationen von Richterinnen in der Schweiz' in R Ludewig, K Weislehner and E Angehrn (eds), Zwischen Recht und Gerechtigkeit: Richterinnen im Spiegel der Zeit (Bern, Stämpfli).

Maag, R (2007) 'Haben Frauen eine andere Konfliktwahrnehmung und andere Lösungen?' in R Ludewig, K Weislehner and E Angehrn (eds), Zwischen Recht und Gerechtigkeit: Richterinnen im Spiegel der Zeit (Bern, Stämpfli).

Malleson, K (2003) 'Justifying Gender Equality on the Bench: Why Differences Won't Do’ 11 Feminist Legal Studies 1.

Menninger, W (1981) in M Middleton, 'Judges Told how to Deal with Stress' 67 American Bar Association Journal 1100.

Niquille, M (2007) 'Richterinnen der zweiten Generation in veränderten Rahmenbedingungen?' in R Ludewig, K Weislehner and E Angehrn (eds), Zwischen Recht und Gerechtigkeit: Richterinnen im Spiegel der Zeit (Bern, Stämpfli). 


\section{Revital Ludewig and Juan LaLlave}

Peresie, JL (2005) 'Female Judges Matter: Gender and Collegial Decision-making in the Federal Appellate Courts' 114(7) Yale Law Journal 1759.

Portnoy, SM (2004) 'The Role of Judges in Keeping Difficult Parties Contained in Court' 18(3) American Journal of Family Law 131.

Ptacek, JT, Smith, RE and Zanas, J (1992) 'Gender, Appraisal, and Coping: A Longitudinal Analysis' 60(4) Journal of Personality and Social Psychology 747.

Roach Anleu, S and Mack K (2005) 'Magistrates' Everyday Work and Emotional Labour' 32(4) Journal of Law and Society 590.

Sander, G and Hartmann, I (2009) 'Erhöhter Stress bei weiblichen Führungskräften' in G Frank, and WR Kromm (eds), Leadership and Health-Weshalb die Folgen schlechter Führung kein Arzt heilen kann (Düsseldorf, Symposion Publishing $\mathrm{GmbH})$.

Schultz, U and Shaw, G (2003) (eds), Women in the World's Legal Professions (Oxford, Hart Publishing).

— (2008) Editorial: 'Gender and Judging' 15 International Journal of the Legal Profession 1.

Sommerlad, H (2002) 'Women Solicitors in a Fractured Profession: Intersections of Gender and Professionalism in England and Wales' 9(3) International Journal of the Legal Profession 213.

Tversky, A (1977) 'Features of Similarity' 84(4) Psychological Review 327.

Wagner, U, Christ, O and Dick, RV (2003) 'Belastungen und Befindlichkeiten von Lehrerinnen und Lehrern' in A Abele, EH Hoff and HU Hohner (eds), Frauen und Männer in akademischen Professionen. Berufsverläufe und Berufserfolg (München, Asanger).

Zimmerman, IM (2006) 'Helping Judges in Distress' 90(1) Judicature 10.

Zuriff, GE (2006) 'Judgments of Similarity are Psychological: The Importance of Importance' 61(6) American Psychologist 641. 